\title{
INTERSTATE RENDITION: EXECUTIVE PRACTICES AND THE EFFECTS OF DISCRETION
}

THE impact of the federal system on the efficient administration of criminal justice across state borders was foreseen early in American constitutional history. Article IV of the Federal Constitution explicitly provides that a state shall extradite a fugitive criminal upon demand by the state in which the crime was committed. ${ }^{1}$ With the Rendition Act of $1793,{ }^{2}$ Congress, aware that the constitutional provision might not be self-enforceable, ${ }^{3}$ placed the executive authority of an "asylum" state under a duty to deliver a properly accused fugitive to the "demanding" state." The Supreme Court has interpreted this duty to be ministerial and not discretionary, once a fugitive has been substantially charged with a crime under the formal requirements of the Rendition Act. ${ }^{5}$

However, the governor of an asylum state is often motivated to exercise discretion in individual cases. Uniformly, governors conduct hearings, osten-

1. "A person charged in any State with Treason, Felony, or other Crime, who shall flee from Justice, and be found in another State, shall on Demand of the executive Authority of the State from which he fled, be delivered up to be removed to the State having Jurisdiction of the Crime." U.S. CoNST. art. IV, $\$ 2$, cl. 2. This provision is similar to a clause in article IV of the Articles of Confederation, which in turn was derived from colonial practices particularly in the New England Confederation. 2 Moore, ExTRAditron $\$ \$$ 517-20 (1891) ; Hoague, Extradition Betzeen States, 13 AMr. L. Rev. 181, 186-\$9 (1879). Article IV was designed to preclude any right of asylum that existed in international extradition; this was the reason for the all inclusive term "other crime." Gatewood v. Culbreath, 47 So. 2d 725 (Fla. 1950); 2 MIOoRe, Extradition \$\$ 521-28 (1891).

The terms "rendition" and "extradition" are used interchangeably by some authorities to describe the return of fugitives under article IV, although other writers state that rendition should be used to refer to interstate practice and extradition to international practice, e.g., Scotr, INTERSTATE Rendition $\$ 1$ (1917). The terms will be used interchangeably in this comment.

Much of the data on current extradition practice reported in this comment has been gathered from forty-one letters received by the Yale Law Journal in reply to a questionnaire sent to all forty-eight states, the District of Columbia, the territories of Alaska and Hawaii, and the Commonwealth of Puerto Rico. The letters are on file in the Yale Law Library ; throughout this Comment they will be cited as "Letters."

2. 1 STAT. 302 (1793), as amended, 18 U.S.C. $\$ 3182$ (1952).

3. 2 Moore, Extradrtion $\$ \$ 531-35$ (1891) ; Hoague, supra note 1, at 181, 192-98.

4. Although there is no constitutional requirement that the asylum governor handle extradition matters, statutes have codified the tradition of gubernatorial control of rendition. See note 12 infra.

5. Kentucky v. Dennison, 65 U.S. (24 How.) 66, 106 (1861) ; Roberts v. Reilly, 116 U.S. 80 (1885) ; 2 Moore, Extradition $\$ \$ 607-11$ (1891) ; Address by Governor Ansel of South Carolina, 2 Proceedings of Goverrors' Conference 138-39 (1910) (hereinafter cited as Governors' Conferexce). See also Uniforar Criminal Extradition Act $\$ 2$. The governor is not confronted with the necessity of exercising his ministerial duty when, as frequently occurs, fugitives waive extradition. E.g., Moorhead, Texas and Interstate Rendition, 23 Texas L. Rev. 22S, 241-43 (1945) ; Letter from Delaware. 
sibly to determine whether demanding states have complied with constitutional and statutory requirements for rendition. ${ }^{6}$ Public and private pressures surrounding the proceedings, equitable considerations presented by the alleged fugitive at the hearing, or the governor's own views of the criminal law of the demanding state often result in a denial of rendition despite compliance with formal requirements. ${ }^{7}$ This action, not based on any recognized constitutional or statutory ground, often results in interstate friction and retaliatory measures, defeating the harmony and efficiency which the constitutional provision was designed to insure. ${ }^{8}$

Existing enforcement machinery on both state and federal levels is inadequate to prevent executive exercise of discretion. Influenced by the concept of state sovereignty and the possibility of gubernatorial disregard of federal decrees, the Supreme Court in Kentucky v. Dennison refused to issue mandamus to enforce compliance with the governor's ministerial obligation. ${ }^{9}$ Nor has state legislation, supplementing the federal constitutional provision, ${ }^{10}$ precluded the use of discretion. The Uniform Criminal Extradition Act, in force in almost all jurisdictions, ${ }^{11}$ emphasizes the exclusively ministerial nature of the governor's duties. ${ }^{12}$ However, no asylum state court has apparently been

6. See notes $22-23$ and $37-40$ infra and accompanying text.

7. See notes $61,63,47$ and 58 infra and accompanying text.

8. See notes $69-78$ infra and accompanying text.

9. 65 U.S. (24 How.) 66 (1861). See High, Extraordinary Legar Remedies $§ 124$ (3d ed. 1896). The Dennison case involved the original jurisdiction of the Supreme Court in a suit between states, U.S. CoNst. art. III, $\$ 2$, cls. 1,2 ; it is the only case in which the Court was asked to issue a writ of mandamus to a governor. For further evaluation of Demison see notes 79-84 infra and accompanying text. The draftsmen of the Constitution made no reference to the rendition situation when they considered the powers of the federal judiciary. Warren, The Making of The Constitution 531 (1947). See also note 16 infra.

10. It was early indicated that the states could pass legislation not inconsistent with the Federal Constitution and statute. See 2 Moore, Extraditron \$\$ 542-43 (1891); cf. Prigg v. Pennsylvania, 41 U.S. (16 Pet.) 536 (1842) ; Moore v. Illinois, 55 U.S. (14 How.) 13 (1852). See generally, State v. Parrish, 242 Ala. 7, 5 So. $2 d 828$ (1941); Note, Constitutional Aspects of State Extradition Legislation, 28 IND. L.J. 662 (1952). See also notes 44 and 93 infra.

11. The act is now in force in forty-one jurisdictions. 9 UnIforar Laws ANN. 65 (Supp. 1955). The Uniform Criminal Extradition Act was drafted by the Commissioners on Uniform State Laws in 1926, and, as later amended, was recommended for adoption by the Interstate Commission on Crime. 9 UnIFord Laws ANn. 169-72 (1951). The latter organization was an outgrowth of the attorney-general's conference on the interstate crime wave of the early thirties. Atrorney-General's Conference on Crime (1934). See, generally, Handbook on Interstate Crine Control \&-30 (rev. ed. 1949).

Prior to the passage of the uniform act several proposals were made to change the federal statute to make it more definitive. See Cockrild, Statenrent of Law Concerning Domestic Fugitives From Justice (1874); Moore, The Difficulties of Extradition, 1 Acad. Poz. Scr. Proc. 625, 633, 634 (1911); Spear, The Nezw Extradition Bill, 37 Albany L.J. 88 (1888).

12. Uniform Crminal Extradition Act $\S 2$. The Federal Rendition Act does not use the word "governor" but refers to the "executive authority" of the asylum state. 18 
called upon to compel rendition. Many courts, reasoning that the separation of powers immunizes the executive from judicial control, would undoubtedly refuse mandamus were it requested $;{ }^{13}$ other courts which ordinarily do issue a writ of mandamus when the gubernatorial function is ministerial, ${ }^{14}$ would probably refuse to enlarge upon the Dennison rationale. ${ }^{15}$ Thus a governor's duty under the Constitution and the federal statute becomes only a "moral duty," unenforceable by the demanding state. ${ }^{10}$

U.S.C. $\$ 3182$ (1952). Some state statutes explicitly make the governor's duty discretionary. MAss. ANN. Laws c. $276, \S 12$ (Supp. 1955) ("The governor may cause to be arrested and delivered up to the executive authority of any other state"); LA. REv. STAT. ANN. $\$ 15: 160$ (West 1951) ("the governor may, in his discretion, issue and direct . . . a warrant") ; WASH. Rev. Code ANN. $\$ 10.88 .020$ (Supp. 1955) (governor shall issue a warrant when satisfied that the demand for rendition is "conformable to law, and ought to be complied with").

13. Eighteen states refuse to direct a writ of mandamus to the governor under any circumstances. Sherwood, Mandamis to Review State Administratize Action, 45 MicH. L. REv. 123, 131 (1946). See, e.g., State ex rel. Axelroad v. Cone, 137 Fla. 496, 188 So. 93 (1939). See, gcnerally, Mechem, Public Offices and Officers $\$ \$ 954-56$ (1890) ; Myers, Mandamus Against a Governor, 3 Mrch. L. REv. 631, 634 (1905).

14. Twenty states will direct a governor to perform a ministerial function. Sherwood, supra note 13 , at 126 . Courts uniformly deny mandamus where a governor's duty is discretionary. MECHEM, op. cit. supra note 13. See, generally, Kopelman, Extradition and Rondition, 14 B.U.L. Rev. 581, 634 (1934); Annot., 105 A.L.R. 1124 (1936).

15. Although no cases have arisen in jurisdictions which allow a writ of mandamus against a governor, dicta of other courts indicate that the governor cannot be compelled, relying primarily on United States Supreme Court opinions, e.g., Drew v. Thaw, 235 U.S. 432 (1914); Taylor v. Taintor, 83 U.S. (16 Wall.) 366 (1873); Kentucky v. Dennison, 65 U.S. (24 How.) 66 (1861); see note 9 supra, rather than on the general judicial policy against issuing mandamus on a governor in any situation, note 14 supra. E.g., People $e x$ rel. Carr v. Murray, 357 Ill. 326, 332, 192 N.E. 198, 200 (1934) ; Ex parte Cohen, 23 N.J. Super. 209, 215, 92 A.2d 837, 840 (App. Div. 1952) ; People ex rel. Higley v. Millspaw, 257 App. Div. 40, 41, 12 N.Y.S.2d 435, 437 (3d Dep't), rev'd on other grounds, 281 N.Y. 441,24 N.E.2d 117 (1939).

16. Kentucky v. Dennison, 65 U.S. (24 How.) 66, 107 (1861) ; Hanilton, A SECoNd Constitution for the United States 33 (1938) ; Address by Governor Stewart of Montana, Governors' Conference 183 (1914). For a criticism of the moral obligation theory see Hoague, supra note 1, at 238-43, and notes $81-82$ infra and accompanying text. The recognition of the nature of governor's obligation is not restricted to legal writings. See, c.g., 22 SURVEY GRAPHIC 94-95 (1933).

Realization that lack of enforcement makes the executive duty discretionary continues. Letters from Mich. ("A governor ... has the widest kind of discretion and may withhold his warrant for any reason that appeals to him"); N.M. ("It would appear that the chief executive has broad discretion to either grant or not grant the extradition") ; Ore. ("While common law gives the Executive wide discretion, I do not feel that the Executive should sit in judgment on the facts concerning the case").

At the Constitutional Convention there was little discussion on article IV and none on the nature or enforceability of the asylum state's duty. WARREN, op. cit. supra note 9 , at 562-63; Note, 2 MIIss. L.J. 240, 241-42 (1929). The main concern was over the companion fugitive slave provision, U.S. CoNst. art. IV, $\$ 2$, cl. 2 . See WARREN, op. cit. supra note 9, at 561-63; Prescott, Drafting the Federal Constitution 726-28 (1941). For many years after the adoption of the Constitution governors did not exercise discretion. However, 
This study will review current rendition procedure, directing particular attention to those areas in which denial of rendition offers constant danger of interstate discord. ${ }^{17}$ A solution will then be offered with a view to obviating the most serious barriers to an efficient rendition system within the framework of existing practice.

\section{Executive Hearing Procedure}

On receipt of the documents containing a request for rendition, ${ }^{18}$ the governor of the asylum state determines whether they conform to the requirements of the Federal Rendition Act and the statutory procedures of the asylum state. ${ }^{19}$ Once conformity is established, an extradition warrant for arrest of

beginning in the 1830's, several executives refused delivery particularly in those cases where the request was alleged to be for an ulterior motive such as debt collection. $C f$. note 41. infra and accompanying text. In some states the language of rendition statutes gave a right of discretion. See Larremore, Inadequacy of the Present Federal Statute Regulating Interstate Rendition, 10 Colun. L. Rev. 208, 217-19 (1910). The early theory of discretion culminated in Taylor v. Taintor, 83 U.S. (16 Wall.) 366 (1873), where the Court held, inter alia, that the asylum had discretion to retain jurisdiction if the fugitive was held by the laws of the asylum. Id. at 371, 373-74. The governor of Massachusetts interpreted the decision as permitting the executive to look behind the requisition and inquire into the good faith of the demanding state. Hoague, supra note 1 , at 183-S4. Cf. Work v. Corrington, 34 Ohio St. 64 (1877).

The discretion exercised by governors and sometimes granted by statute is discretion in the broad sense. It must be distinguished from the inquiry into the constitutional questions of fugitivity and substantial charge which are reviewable by the courts when rendition is granted, see notes 38 and 40 infra and accompanying text. See In rc Perry, 2 CrIm. L. Mag. 84 (D.C. 1881) ; In re Murphy, 321 Mass. 206, 72 N.E.2d 413 (1947) ; People $c x$ rel. Draper v. Pinkerton, 17 Hun. 199, 202 (2d Dep't N.Y. 1879).

17. See notes 69-78 infra and accompanying text. The importance of the problem is demonstrated by the large number of demands for rendition received annually by asylum states, e.g., Letters from Cal. (435), Ga. (250), Ind. (196), Md. (100), Mass. (80), Mich. (150), N.M. (130), Tex. (200), and the average refusal rate for all reasons, c.g., Letters from Ariz. (5\%), Mich. (approximately 9\%), Tenn. (5\%).

18. These documents usually consist of a requisition and a copy of an indictment, information or affidavit. The Federal Rendition Act provides that an "indictment" or "affidavit made before a magistrate" is required before the asylum governor must act. 1S U.S.C. $\S 3182$ (1952). In addition, the uniform state statute compels the governor to act when he is faced with an "information supported by affidavit." Uniforar Crinrinal Extradition ACT $\$ 3$. For a comprehensive statement of what an asylum statute may require, see Mich. STAt. ANN. $\$ 28.1285$ (3) (1954). If the federal statutory requirements are more exacting than those of the asylum, the latter's prerequisites may control. Stark v. Livermore, 3 N.J. Super. 94, 65 A.2d 625 (App. Div. 1949) ; People ex rel. Matochik v. Baker, 396 N.Y. 32, 114 N.E.2d 194 (1953). Where the federal requirements are less exacting than the state ones, the former may be followed. State ex rel. Cutshaw v. Smith, 127 N.E.2d 633 (Ohio App. 1953).

The present requirements prior to the demanding governor's issuance of a requisition are codified in UNIFORM CRIMINal Extradition ACT $\$ 23$. Many governors indicate that $\$ 23$ is not strictly complied with. See Letters from Mich., N.C., Pa.; cf. Kan., Md., N.M. Contra, Letter from Tex.

19. If the papers are technically defective the governor may refuse rendition, forcing the demanding state to repeat its procedure, or he may return the papers for technical cor- 
the fugitive is issued. ${ }^{20}$ Although an accused has no legal right to a hearing, ${ }^{21}$ most governors will grant one upon timely demand by the alleged fugitive $;^{22}$ some governors conduct hearings as a matter of course.,3

The procedure followed in executive hearings is substantially identical in all jurisdictions. Although the governors of many states preside personally at the hearings, ${ }^{21}$ the proceedings are usually conducted by administrative officials, often recruited from the attorney-general's department. ${ }^{25}$ The degree of ad-

rections without making a final determination. See note 39 infra. See also Letters from Mich. (formal defect merely defers rendition) and N.M. A discharge because of formal defects is not res judicata. Reed v. Colpoys, 99 F.2d 396 (D.C. Cir.), cert. denied, 305 U.S. 598 (1938).

20. See Uniforar Criminal Extradition Act $\$ \S 7,8$. The fugitive may be arrested prior to the governor's action if detention is necessary to preclude continued flight. UNIrorar Canminal Extradition ACT $\$ 13$. Section 14 provides for arrest without a warrant. See generally, Green, Duties of the Asylum State Under the Uniform Criminal Extradition Act, 30 J. Asr. Inst. Cring. L. \& C. 295, 308-11 (1939).

21. Munsey v. Clough, 196 U.S. 364 (1905) ; Young v. Stoutamire, 129 Fla. 805, 176 So. 759 (1937) ; Ex parte Colier, 140 N.J. Eq. 469, 55 A.2d 29 (Ct. Err. \& App. 1947), cert. denied, 333 U.S. $\$ 29$ (1948).

22. Letters from Ariz., Cal., D.C., Hawaii, Idaho, Ill., Ind., Iowa, Kan., Me., Mich., Mo., Mont., Nev., N.J., N.M., N.C., Okla., Ore., P.R., S.C., S.D., Tenn., Tex., Utah, Wash., W.Va., Wis. In some jurisdictions hearings are only granted in limited circumstances. Letters from Conn. (demand for hearing must be prior to receipt of extradition papers); Miss. (preliminary investigation to see if facts warrant hearing); Neb. (where facts warrant a hearing) ; N.Y. (only in special cases) ; Pa. (only where fugitive has previously "protested" against the proceeding). One jurisdiction considers the rendition duty mandatory in all cases and grants no hearing. Letter from Alaska.

The demand for a hearing is informal; it must only be sufficient to give the asylum governor notice not to issue an extradition warrant as a matter of course. Moorhead, supra note 5 , at 236 . The demand can apparently be made after the preliminary arrest, see note 20 supra, or after the governor's issuance of an extradition warrant, the governor recalling the warrant for purposes of the hearing. See UnIForar CRIMIINAL EXTradition ACT $\S 21$.

23. Letters from Del., MId. (monthly hearings scheduled), Mass., Ohio, Vt. North Carolina followed this practice under a prior governor.

24. Letters from Conn., Idaho, Ind., Iowa, Miss., Mo., Mont., Neb., Nev., Ore., S.D., Tenn., Utah, Vt. Even if an administrative official usually presides, the governor may choose to sit at a particular hearing. See Life, June 22, 1953, pp. 47-48 (Governor Stratton conducted hearing); Letter from Illinois (Legislative Reference Bureau generally presides).

25. Letters from Cal. (Extradition Secretary), Ill. (Legislative Reference Bureau), Kan. (pardon attorney), Md. (administrative assistant in office of Secretary of State), Mich. (governor's legal advisor), N.C. (member of State Board of Paroles), Ohio (Executive Secretary), Okla. (governor's counsel specially employed for this purpose), Tex. (Secretary of State), Wash. (assistant to governor), Wis. (governor's executive or legal counsel). In a large group of states the attorney-general's office conducts the hearing. Letters from Ariz., Del., Ga., Me., Mass., N.J., N.M., Pa., R.I., S.C. (sometimes conducted by governor's legal assistant), W.Va. In the District of Columbia the Chief Judge of the District Court assumes the executive position and conducts the hearing. D.C. CoDE ANs. § 23-401 (Supp. III 1951); Letter from District of Columbia. In two jurisdictions the hearings are before judges of courts of record. Letters from Hawaii and P.R. 
herence to legal rules of evidence categorize hearings as judicial, semi-judicial or informal, ${ }^{26}$ but even in judicial-type hearings, evidentiary requirements are not followed strictly. ${ }^{27}$ The proceeding is an adversary one: the demanding state is represented by an official of the asylum state, ${ }^{28}$ or, when notice of the proceedings has been given, by one of the demanding state's own officials. ${ }^{20}$ The accused has the burden of contravening the allegations of the requisition document. ${ }^{30}$ If the governor of the asylum state has not presided at the hearing, the presiding officer prepares a report which is formal in some jurisdictions, informal and often verbal in others. ${ }^{31}$ Frequently the governor receives a transcript of the testimony at the hearing. ${ }^{32}$ The hearing officer typically submits a recommendation with the report, ${ }^{33}$ and the suggested course of action is usually controlling. ${ }^{34}$ If the governor decides to deny rendition he

26. Judicial hearings follow courtroom procedure and adhere most closely to the rules of evidence. They are conducted in Ariz., Cal., Ga., Hawaii, Idaho (but conducted along "informal lines"), Kan., Ohio, Pa., P.R. In semi-judicial hearings the rules of evidence are usually followed, the "semi" designation probably referring to the non-courtroom procedure in other respects. See Letters from Del. and S.C. They are conducted in Del., D.C., S.C., Tenn. Informal hearings are conducted in Ill., Iowa, Me., Md., Mich., Miss., Mo., Mont, Neb., N.M., Okla., Ore., S.D., Tex., Utah, Vt., W.Va., Wash. For a description of an informal hearing with broad rules of admissibility, see Moorhead, supra note 5 , at 236. Since there is no right to a hearing, no particular form of hearing is required. Willin v. Sheriff, 201 Md. 667, 95 A.2d 87 (1953).

27. See Letters from Ariz., Cal., Ga. There seems to be no correlation between states which employ loose evidentiary standards and those that most frequently deny extradition.

28. E.g., Letters from Cal., Conn., Ga., Ind., Iowa, Mo., Ohio, Tenn., Wis. The asylum official is generally from the attorney-general's office. Often an asylum official aids the demanding state even when the latter has its own representative present.

29. Glander, Practice in Ohio Under the Uniform Criminal Extradition Act, 8 OH1o Sr. L.J. 255, 260 (1942). Cf. Letter from Oklahoma ("In cases where the interest warrants it the demanding state is represented"). But see Letter from Michigan ("gives the demanding state the opportunity to appear").

Many states not only recognize the propriety of having the demanding state present at the hearing but are also aware of the prejudicial effect to the demanding state when there are neither witnesses who can identify the fugitive nor officials who are familiar with the facts of the case. Letters from Ariz., Idaho, Iowa, Wash.

30. See Letters from Me. and Tex.

31. Formal reports are used in most jurisdictions. Letters from Ariz., Cal., Hawaii, I11. (only when requested by governor), Me., Mass., N.J., N.M., N.C., Ohio, R.I., S.C., Tenn. (only when requested), W.Va., Wis. (only when requested). Other jurisdictions use informal reports. Letters from Mich. (no report unless legal advisor recommends refusal on policy grounds), Miss., Okla., Wash.

32. E.g., Letters from Ariz., Me., Mass., Mo., N.M., S.C.

33. E.g., Letters from Del., N.M., N.C., W.Va. In some jurisdictions it appears that recommendations are submitted without detailed reports. Letters from Kan., Me., Mid., Okla., Pa., S.C., Tex., Wis. Cf. Letters from Ga., Idaho, P.R.

34. Letters from Cal. (sometimes decision is overruled), Ga., Hawaii, I11., Kan., Me. (some decisions overruled), Md., Mich., N.M., N.C., Okla., Pa. (no record of any reversals), S.C., W.Va. Although under the Uniform Criminal Extradition Act $\$ 4$ the governor may authorize the attorney-general to investigate the case, the governor need not follow that official's recommendation. In re Murphy, 321 Mass. 206, 72 N.E.2d 413 (1947). 
usually notifies the demanding state and sets forth a complete statement of his reasons, explaining that the constitutional requirements were not met or that the merits warrant refusal. ${ }^{35}$ However, the executive may choose to deny the requisition relying on minor technical defects in the requisition papers, or without giving any reason to the demanding state. ${ }^{36}$

\section{Grounds For Refusals of Rendition}

\section{Constitutional Grounds}

The two constitutional prerequisites to rendition are that the accused be charged with a crime and that he be a fugitive from the demanding state. ${ }^{37}$ In every state a governor will deny rendition where he finds these requirements lacking, and at all executive hearings an alleged fugitive is permitted to introduce evidence that he is not a fugitive or that the demanding state's requisition does not substantially charge him with a crime. ${ }^{38}$ For example, the requisition papers may be defective in form, or the activity for which rendition is sought

35. See N.Y. Times, Feb. 19, 1929, p. 30, cols. 1-2 (Governor Roosevelt of New York sent letter to Massachusetts, giving detailed reasons for refusing rendition) ; Letters from Miss. and Okla. The incomplete refusals referred to in note 71 infra seem to be exceptional.

36. See Letters from Mich., N.M., N.C., Pa. Cf. N.Y. Times, April 12, 1950, p. 4, col. 4 (fugitive discharged by court after California governor takes no action on requisition).

If the governor grants rendition, the fugitive who is arrested pursuant to the extradition warrant can petition a court for a writ of habeas corpus to question his detention. Roberts v. Reilly, 116 U.S. 80 (1885). See also 2 Moore, Extradition $\$ \$ 628-41$ (1891). Since the fugitive is detained by asylum state officers he can apply to an asylum state court. Uniform Criminal Extradimon Act $\$ 10$. And because the Federal Constitution is the basis for his custody a federal district court in the asylum has concurrent jurisdiction. Robb v. Connolly, 111. U.S. 624 (1884). But once the fugitive has chosen his forum the doctrine of nonintervention prevents him from removing the proceeding to the other court if he is denied relief in the first. Ibid.; Note, 45 Y ALE L.J. 543 (1936); cf. note 58 infra. But cf. United States ex rel. McCline v. Meyering, 75 F.2d 716 (7th Cir. 1934).

An arbitrary denial of the fugitive's right to habeas corpus is not a defense at a trial in the demanding state. See note 58 infra. However, depriving the fugitive of his right to a judicial hearing prior to rendition may constitute a crime. OHIo REv. CODE ANN. tit. 29, $\S$ 2963:09 (Page 1953). Cf. Picking v. Pennsylvania R.R., 151 F.2d 240, 250 (3d Cir. 1945).

37. See, c.g., Roberts v. Reilly, 116 U.S. 80 (1885). Although either a state or federal statute is interpreted in all rendition cases, the requirements of fugitivity and substantial charge rest on the Constitution or on statutory interpretations of the Constitution.

38. E.g., Letters from Ariz., Cal., Ga., Iowa, S.D., Tenn. Governors are justified in denying rendition where constitutional requirements are lacking. E.g., Ex parte Brewer, 61 Cal. App. 2d 388, 143 P.2d 33 (1943) ; Audler v. Kriss, 197 Md. 362, 79 A.2d 391 (1950); Commonwealth ex rel. Henderson v. Baldi, $372 \mathrm{~Pa} .463,93 \mathrm{~A} .2 \mathrm{~d} 458$ (1953). Where the fugitive has a criminal prosecution pending in the asylum, the governor may also refuse to extradite until the laws of the asylum are satisfied. UnIform CRIMINAL Extradition Acr $\S 19$. The asylum may also keep the fugitive until he has completed his sentence there. Taylor v. Taintor, 83 U.S. (16 Wall.) 366, 371 (1873) ; Carpenter v. Lord, 88 Ore. 128, 134, 171 Pac. 577, 579 (1918). The asylum governor's discretion is unchallenged in these situations. See, generally, Note, 48 Colux. L. Rev. 1190, 1200-06 (1948); note 16 supra. 
may not constitute a crime in the demanding state. ${ }^{39}$ An accused may also prove that he was not present in the demanding state when the crime was committed and therefore is not a fugitive in the technical sense. ${ }^{40}$ The defense of no substantial charge is frequently raised by a contention that rendition is being used as a means to obtain jurisdiction over the accused for collection of a civil debt. The criminal charge is alleged to be unsubstantial because it will be dropped once civil jurisdiction is obtained. Although governors regularly deny rendition in debt cases, they rarely adopt the no-substantial-charge ration-

39. E.g., Drew v. Thaw, 235 U.S. 432 (1914); Commonwealth ex rel. Hunt v. Groman, 169 Pa. Super. 68, 82 A.2d 278 (1951) ; Green, supra note 20, at 297-98. The demanding state, however, does not have to conform to strict requirements of criminal pleading to charge a crime for rendition purposes. E.g., Pierce v. Creecy, 210 U.S. 387 (1908); E.x parte Paulson, 168 Ore. 457, 124 P.2d 297 (1942).

A typical defect is failure to have a proper indictment, information or affidavit. Ste note 18 supra. Some governors make a preliminary determination of compliance with formal requirements before the actual hearing. Letters from Mo., Ore., Tex.

Since a person cannot be substantially charged if he is not the individual described in the rendition papers, the identity of the fugitive is also a proper subject of inquiry. UNIform Crininal Extradition Act $\$ 20$; Scott, Interstate Renditton $\$$ 108-18 (1917); Letters from Kan., Okla., S.C.

On habeas corpus review the substantial charge question is one of law and courts will re-examine it de novo just as they redetermine the formal sufficiency of the requisition papers. Roberts v. Reilly, 116 U.S. 80 (1885). Courts also inquire into the identity of the accused. E.g., People ex rel. Gilbert v. Babb, 415 I1l. 349, 114 N.E.2d 358 (1953). Any presumption created by the governor's warrant can be overcome by evidence to the contrary. Ex parte Grabel, 248 S.W.2d 343 (Ky. App. 1952) ; Ex parte Gorham, 242 S.W.2d 425 (Tex. Crim. 1951).

40. Ex parte Brewer, 61 Cal. App. 2d 388, 143 P.2d 33 (1943) ; O'Malley v. Quigg, 172 Ind. 350,88 N.E. 611 (1909).

The circumstances under which the accused left are irrelevant. The fact that he entered the asylum state under compulsion will not change his status as a fugitive. Moulthrope $v$. Matus, 139 Conn. 272, 93 A.2d 149 (1952) ; State ex rel. Shapiro v. Wall, 187 Minn. 246, 244 N.W. 811 (1933). A parolee who enters the asylum with permission of the demanding state is still a fugitive for purposes of rendition when the parole is revolked. Ex parto McBride, 101 Cal. App. 251, 281 Pac. 651 (1929) ; see note 93 infra.

However, since the governor's denial of rendition is not subject to review he can give a broader concept to fugitivity and consider the intention of the fugitive when he left the state, for example whether he fled or left peacefully. 2 MOoRE, Extraditron $\$ \$ 562-\$ 0$ (1891); Note, 2 CRIM. L. MAG. 90 (1881). The letters from the various jurisdictions indicate that today governors follow the legal concept of fugitivity; no letter refers to the use of a broader definition in order to deny rendition.

On habeas corpus review the governor's rendition warrant is prima facie proof of fugitivity. Munsey v. Clough, 196 U.S. 364, 372 (1905); People ex rel. Chevlin v. O'Brien, 372 Ill. 640, 25 N.E.2d 4 (1939) ; Stark v. Livermore, 3 N.J. Super. 94, 65 A.2d 625 (App. Div. 1949). Merely contradictory evidence will not overcome the presumption created by the governor's warrant. McNichols v. Pease, 207 U.S. 100 (1907); Audler v. Kriss, 197 Md. 362, 79 A.2d 391 (1951). This is particularly true where a hearing has been held. See Ex parte Riccardi, 68 Ariz. 180, 203 P.2d 627 (1949) ; Ex parte Germain, 258 Mass. 289, 155 N.E. 12 (1927). 
ale but base their refusals on a traditional policy against use of rendition for private purposes. ${ }^{41}$

Typically a valid defense of non-fugitivity arises in cases where an accused is charged with the offense of nonsupport. ${ }^{42}$ Since this crime is usually committed after the nonsupporter has left the demanding state, he cannot be extradited under the authority of article IV. ${ }^{43}$ However, uniform statutes operating in addition to the constitutional provision give the asylum governor discretionary power of extradition in this area.44 Governors exercise their discretionary power regularly. In practice, they deny rendition only if the aggrieved party has failed to obtain available civil relief under the Uniform Reciprocal Enforcement of Support Act, ${ }^{45}$ or if the accused holds employment that will permit him to pay a civil support decree. ${ }^{46}$

41. Letters from Cal., Mich., Miss., Mo., Mont., Neb., N.J., N.M., N.C., S.D., Utah, W.Va. See also Address by Governor Shafer of North Dakota, Governors' Conference 57, 64 (1931) ; Moorhead, Texas and Interstate Rendition, 23 Texas L. Rev. 228, 237 (1945).

Where judicial inquiry reveals that extradition is being used for debt collection purposes courts similarly deny rendition without articulating a substantial charge rationale. E.g., Russell v. State, 251 Ala. 268, 37 So. 2 d 233 (1948); State ex rel. Hourigan v. Robinson, 195 Tenn. 101, 257 S.W.2d 9 (1953) ; N.Y. Times, Dec. 23, 1948, p. 40, col. 1.

A similar problem may arise where a person is charged with a crime in order to have him appear as a witness at a criminal trial in the demanding state. See Hoague, Extradition Between States, 13 Axr. L. REv. 181, 183-S4 (1879) ; Spear, Interstate Extradition Procedure, 18 ALBANY L.J. 187, 208 (1878). However, the letters received do not refer to witness cases in recent years, probably because of the adoption of the Uniform Act to Secure Attendance of Witnesses. See notes 94-95 infra and accompanying text.

42. E.g., People ex rel. Randolph v. Meyering, 384 IIl. 17, 180 N.E. 560 (1932) ; Drumm v. Pederson, 219 Iowa 642,259 N.W. 208 (1935).

43. See note 40 supra and accompanying text.

44. Uniforar Criminal Extradition ACT § 6; Uniform Reciprocal Enforcenent OF SUPporr ACr $\$ 5$. Although the nonsupporter can be extradited under either law, the Criminal Extradition Act is aimed at the interstate criminal who commits a crime in the demanding state while physically present in another state. This criminal is not subject to rendition under the federal statute since he is a non-fugitive. Innes v. Tobin, 240 U.S. 127, 131 (1916). On the Support Act see, generally, Reid, Interstate Extradition for Extraterritorial Crimes, 45 A.B.A. REP. 432 (1920). Both discretionary sections have been held constitutional. Ex parte Morgan, 78 F. Supp. 756 (S.D. Cal. 1948) ; Ex parte Bledsoe, 93 Okla. Crim. 302, 227 P.2d 680 (1951) ; State ex sel. Bryant v. Fleming, 195 Tenn. 419, 260 S.W.2d 161 (1953). See note 10 supra.

45. See Letters from Me., Mass., Mich., N.M., Ore., S.C., Utah; cf. Letters from Mont. and Tex.

46. See Letters from III., Md., Mo., Ore., Tex., Utah.

Extradition is also denied for a variety of other reasons, e.g., rearing of a family by the deserter in the asylum following a divorce; likelihood of a settlement; malice of the demandant. See Letters from Ariz., Cal., D.C., Idaho, Iowa, Miss., Tenn., Wash. See also N.Y. Times, March 25, 1925, p. 4, col. 2 (Governor Ferguson of Texas refused extradition because, inter alia, accused had sent wife money, had visited her and left with her consent) ; N.Y. Times, May 28, 1938, p. 3, col. 8; Address by Governor Stewart of Montana, GoverNors' CoNFERENCE 1S2, 187 (1914). Nonsupport denials sometimes employ the same rationale as the debt cases-the charge will be dropped once civil jurisdiction is obtained. See 


\section{Nonconstitutional Grounds: The Merits}

Even if the constitutional requirements are satisfied by the demanding state, some governors may nevertheless refuse rendition on the "merits" of a particular case. Defenses based on the merits can be separated into equitable pleas, substantive defenses to the alleged crime, and due process violations in the demanding state.

The merits argument which succeeds most often is the "equitable plea." This is a claim that the case presents certain facts of an equitable nature which are inconsistent with the granting of rendition. Governors regularly hear these facts and deny rendition where they feel it will serve no just or useful purpose in light of all the circumstances of the case. ${ }^{47}$ Foremost is a plea that the fugitive has been rehabilitated since his flight from prosecution or imprisonment. To prove his reformation the fugitive often shows the length of time he has spent in the asylum state and testimony of good character. ${ }^{48}$ Fugitives also introduce evidence of other equities : a sentence of a long period of imprisonment for a relatively minor offense; the short time remaining to be served in the demanding state; the extended period already served in the demanding state; and illness of the accused. ${ }^{49}$ Each plea is usually made in combination

Address by Governor Shafer of North Dakota, Governors' Conference 57, 65 (1931); Letter from California.

If the governor is exercising the discretion granted by statute to deliver an admitted non-fugitive as in nonsupport cases, courts will rarely attempt to review his action on habeas corpus. See Harrison v. State, 77 So. $2 d 384$ (Ala. App.), cert. denicd, 262 Ala. 701, 77 So. 2d 387 (1955) ; Lincoln v. State, 199 Md. 194, 85 A.2d 765 (1952).

47. Letters from Cal. ("crime was committed many years ago") ; Idaho ("whether or not society would gain by honoring the request") ; Ill. ("seriousness of the offense has considerable bearing on the decision" in rehabilitation cases) ; Mass. ("ends of justice would not be met if the fugitive was returned") ; Mich. ("charges 20 years old"); Mo.; N.J. (escape just prior to expiration of maximum sentence) ; N.M. ("fireside equities") ; S.D. ("long distances" for "trivial offenses"); Utah (charged with a relatively minor offense).

In most of these equitable cases no one factor is determinative; all the circumstances are considered and other merit questions are commonly involved. E.g., Letters from MIo., Ohio, Utah. See also Address by Governor Stewart of Montana, Governors' Conference 182, 197 (1914); cases cited notes 50-51 infra.

Courts at habeas corpus hearings generally refuse to consider "merit" arguments as a defense to denial of the writ. Equitable pleas are held to be properly directed to the demanding governor in his power to pardon. Reed v. Colpoys, 99 F.2d 396, 399 (D.C. Cir.), cert. denied, 305 U.S. 598 (1938) ; Commonwealth ex rel. Huey v. Dye, $373 \mathrm{~Pa} .50 \mathrm{~S}, 96$ A.2d 129 (1953). One dissenting opinion suggested that courts should inquire into equitable matters. Ex parte Parkinson, 271 S.W.2d 638, 641 (Tex. Crim. 1954) (dissenting opinion).

48. E.g., N.Y. Times, March 15, 1952, p. 30, col. 3; Nov. 16, 1951, p. 52, col. 3; May 1, 1953, p. 16, col. 3; Oct. 26, 1939, p. 25, col. 5; Mosk, Extradition Procedure in California, 14 CALIF. ST. B.J. 121, 125 (1939).

49. N.Y. Times, Nov. 16, 1951, p. 52, col. 3 (fugitive had served eleven years of one hundred year sentence for $\$ 67$ robbery committed at age of fourteen) ; N.Y. Times, Aug. 6,1948 , p. 36, cols. 1-2 (fugitive had served nine of nineteen months for housebreaking and stealing $\$ 5$; had escaped seven years prior to requisition) ; N.Y. Times, June 12,1943 , p. 15 , col. 6 (fugitive had served fourteen years of a twenty-two to twenty-five year term for 
with other equitable claims, especially in the rehabilitation context. ${ }^{50}$ The equitable pleas are also likely to be raised in conjunction with contentions of due process violations and with substantive defenses. ${ }^{51}$

Fugitives often present substantive defenses which could properly be raised at a trial on the merits in the demanding state. These include double jeopardy, illegality of revocation of parole, and insanity. ${ }^{52}$ The chief substantive defense presented to governors is a contention of the fugitive's absence from the scene of the crime when it was committed. ${ }^{53}$ Such evidence must be distinguished from valid constitutional defenses of non-fugitivity-the accused was not in the demanding state at the time of the alleged offense ${ }^{54}$-and nonidentity-he is not the person named in the requisition. .55 While rendition is seldom denied on the basis of substantive defenses, alibi evidence seems to meet with some success..$^{56}$

stealing a pack of cigarettes) ; N.Y. Times, Dec. 16, 1932, p. 3, col. 6, and the Literary Digest, Jan. 7, 1933, pp. 9, 10 (fugitive had received six-to-ten year sentence for a $\$ 4.80$ hold-up; had become a successful writer after escape; faced death if returned because of physical condition); N.Y. Times, Feb. 12, 1929, p. 19, col. 3, and Feb. 19, 1929, p. 30, cols. 1-2 (fugitive, wanted for disturbing the peace in Massachusetts textile strike, contended mill owners tried to break his union; Governor Roosevelt of New York, denying extradition, pointed to fugitive's activities in ameliorating working conditions).

50. E.g., N.Y. Times, Nov. 16, 1951, p. 52, col. 3 ; Aug. 6, 1948, p. 36, cols. 1-2.

51. N.Y. Times, Oct. 26,1939 , p. 25 , col. 5 (due process); 138 The Natton 730 (1934) (substantive).

52. Since such cases are not reported it is difficult to find instances where governors have refused rendition because of these defenses. In the following cases governors rejected these contentions: In re Bloch, 87 Fed. 981 (W.D. Ark. 1898) (double jeopardy) ; People ex rel. Coine v. Reilly, 228 App. Div. 427, 240 N.Y. Supp. 27 (2d Dep't 1930) (same); Fowell v. Turner, 167 Kan. 524, 207 P.2d 492 (1949) (parole); Ex parte Trignani, 13 N.J. Super. 306, 80 A.2d 371 (County Ct. 1951) (same) ; State ex rel. Davey v. Owen, 133 Ohio St. 96, 12 N.E.2d 144 (1937) (insanity). But cf. Mosk, supira note 48, at 124; Moorhead, supra note 41, at 236-37; Letters from Idaho and Utab.

53. See Scott, Interstate Rendition $\S 141$ (1917). It is difficult to find cases in which governors have denied rendition because of an alibi. But in a substantial number of cases and alibi defense has been raised. E.g., South Carolina v. Bailey, 289 U.S. 412 (1933); Edmunds v. Griffin, 177 Iowa 389, 156 N.W. 353 (1916) ; People ex rel. Genna v. McLaughlin, 145 App. Div. 513, 130 N.Y. Supp. 458 (2d Dep't 1911); see also Moorhead, supra note 41.

54. See note 40 supra and accompanying text.

55. See note 39 supra. If the fugitive proves an alibi the governor may hold that he is not the man described in the requisition papers even though the names are the same.

56. Even when the rendition refusal could properly be based on the non-fugitivity of the accused, a governor may speak in terms of alibi. N.Y. Times, Dec. 10, 1927, p. 10, col. 4. Cf. Moorhead, supra note 41 ; Letter from Mississippi.

A substantive defense argument is probably raised infrequently because of the common recognition that guilt or innocence of the accused is not to be determined in the asylum state. See Uniform Criminal Extradition Act $\$ 20$; cases cited note 52 supra; Letters from Iowa, N.J., Ohio, Utah, W.Va. But cf. Moorhead, supra note 41; Letter from Michigan.

In international extradition and federal removal practice probable cause must be shown, and the accused may introduce evidence to show his innocence. Curreri v. Vice, 77 F.2d 
Finally, the accused may allege past or prospective due process violations in the demanding state. For example, he may contend that an unfair trial or cruel and unusual punishment awaits him in the demanding state. ${ }^{57}$ Executive hearings regularly consider such evidence, and governors have refused rendition on this ground. ${ }^{58}$

\section{Public and Private Pressures}

The governor's decision is influenced not only by matters raised at the executive hearing but also by various pressures exerted outside the hearing room. Equitable pleas and due process cases elicit widespread public interest, appealing to the news media and evoking the pressure of public opinion. ${ }^{50}$ Often

130 (9th Cir.), cert. denied, 296 U.S. 638 (1935) (international); FED. R. CRIM. P. 40 (removal); In re Cravens, 40 F.2d 931 (W.D. Mo. 1929) (same).

57. E.g., People ex rel. Jackson v. Ruthazer, 90 N.Y.S.2d 205 (Sup. Ct. 1949) ; N.Y. Times, Jan. 18, 1938, p. 2, col. 4 ; Comment, 67 U.S.L. Rev. 58 (1933) ; Note, 2 Mrss. L.J. 240 (1929); Editorial, 12 BENCH \& BAR (n.s.) 280 (1917).

58. Letters from Idaho, Mass., N.J., Ohio, R.I.; N.Y. Times, Aug. 6, 1948, p. 36, cols. 1-2; July 28, 1937, p. 9, col. 2; Dec. 22, 1932, p. 1, col. 4, p. 3, cols. 4-6; Comment, 67 U.S.L. REv. 58, 63-64 (1933). Cf. Letters from Cal., Mo., Utah.

On habeas corpus courts generally refuse to consider due process contentions. Federal courts of the state of asylum reject the arguments on the ground that the fugitive must first exhaust his remedies in the state courts of both the asylum and demanding states. Sweeney v. Woodall, 344 U.S. 86 (1952) ; Johnson v. Matthews, 182 F.2d 677 (D.C. Cir.), cert. denied, 340 U.S. 828 (1950). But cf. Horowitz \& Steinberg, The Fourteenth Amendntent-Its Newly Recognized Impact on "Scope" of Habeas Corpus in Extradition, 23 So. Calif. L. Rev. 441 (1950).

Few asylum state courts deny rendition even where evidence of a due process violation has been introduced and not disproved. Asylum state courts prefer to have a fugitive sue out his remedy in the demanding state. E.g., Ex parte Colier, 140 N.J. Eq. 469,55 A.2d 29 (Ct. Err. \& App. 1947), cert. denied, 333 U.S. 829 (1948); People ex rel. Johnson v. Ruthazer, 198 Misc. 1044, 102 N.Y.S.2d 39 (Sup. Ct. 1950). But cf. Commonwealth ex rel. Mattox v. Superintendent, 152 Pa. Super. 167, 31 A.2d 576 (1943); People ex rel. Reid v. Warden, 63 N.Y.S.2d 630 (Sup. Ct. 1946). There is authority that asylum courts do not have jurisdiction to consider the due process issue. Johnson v. Matthews, supra at 680; Commonwealth ex rel. Brown v. Baldi, 378 Pa. 504, 509, 106 A.2d 777, 779 (1954). For criticism of the policy of the federal and state exhaustion of remedies doctrines, see Sweeney v. Woodall, supra at 91-93 (1952) (dissenting opinion) ; Comment, 1 DUKE B.J. 188, 196202 (1951).

Once a fugitive is in the jurisdiction of the demanding state rendition has succeeded. The courts of the demanding state do not question the means by which jurisdiction was acquired, even though the fugitive was kidnapped, not extradited. Frisbie v. Collins, 342 U.S. 519 (1952) ; Ker v. Illinois, 119 U.S. 436 (1886). Similarly prosecution for a crime not specified in the requisition is permitted. UNIFORMI CRIMINAL Extradirion ACT $\$ 26$; Lascelles v. Georgia, 148 U.S. 537 (1893). The rule in international extradition is to the contrary. United States v. Rauscher, 119 U.S. 407 (1886). However, in interstate rendition, service of civil process, if made possible by rendition, may be quashed if rendition is shown to have been employed solely for that purpose. UnIForar Criminal Extrabition ACT $\$ 25$; Klaiber v. Frank, 9 N.J. 1, 86 A.2d 679 (1952); Note, 6 Mrns. L. REv. 410 (1921).

59. E.g., People ex rel. Jackson v. Ruthazer, 90 N.Y.S.2d 205, 206-10 (Sup. Ct. 1949). 
aligned with the fugitive are numerous permanent and temporary organizations as well as individuals in prominent positions. ${ }^{60}$ This public pressure is often effective in preventing rendition. ${ }^{61}$ Another type of pressure which is less apparent both in operation and effect is the private political pressure that may be found in any type of case. Its presence has been acknowledged in the past. ${ }^{62}$ Because of the nature of this pressure the extent of its contemporary existence can only be surmised, but its continued vitality may be inferred from some rendition denials which are based on no specific reasoning or on minor technical defects in the requisition papers. ${ }^{63}$

\section{EFrects of Rendition Denials}

In most cases denial of rendition does not effect interstate harmony. If the governor bases his refusal on an apparently valid constitutional defense of nonfugitivity or no substantial charge, the demanding governor generally will not question his action. ${ }^{64}$ Although debt collection denials do not rely on a possible substantial charge rationale, such refusals are accepted as consistent with traditional rendition policy. ${ }^{65}$ The governor's denial of rendition in nonsupport cases is not criticized since the admitted non-fugitivity of the accused gives the asylum governor a power of discretion; only an obvious abuse of his authority under the uniform statutes will subject the governor to a charge of unlawful action. ${ }^{60}$ Refusals to grant extradition in rehabilitation and other equitable

60. N.Y. Times, Dec. 18, 1932, p. 3, col. 1; Dec. 20, 1932, p. 40, col. 2; Dec. 22, 1932, p. 1, col. 4, p. 3, cols. 4-6 (hundreds requested New Jersey governor not to extradite chain gang fugitive; Clarence Darrow supported fugitive's position as did governors of Massachusetts and Ohio); Life, June 22, 1953, pp. $47-48$ (petition sent to asylum governor by neighbors of fugitive); N.Y. Times, Dec. 2, 1955, p. 22, cols. 1-3, and Dec. 5, 1955, p. 36, col. 6 (National Council of Churches urged New York governor to consider risk to life of anti-segregationist Negro minister and danger to interests of justice if he were returned to South Carolina; minister asked 500 member congregation to write asylum governor). Cf. N.Y. Times, April 23, 1928, p. 16, col. 2 (200 prominent persons petitioned Oklahoma governor not to request fugitive who had reformed in Hawaii).

61. See, e.g., N.Y. Times, Aug. 6, 1948, p. 36, cols. 1-2; June 6, 1953, p. 31, col. 4 ; Dec. 22, 1932, p. 1, col. 4, p. 3, cols. 4-6.

62. See Address by Governor Stewart of Montana, Governors' Conference 193 (1914); Letter from New Mexico; Note, 92 Cent. L.J. 297, 298 (1921).

63. See Letters from Mich., N.M., N.C., Pa. These refusals may occur more frequently when the executive hearing is held in camera or when there is no hearing. See Letters from Mich. and N.C. But cf. Letter from N.M. The extent to which hearings are open to the demanding state and to the public in general is not known. Cf. Letters from Idaho (hearing conducted in governor's chambers) and Wis. (any interested party may appear).

64. See note 37 supra and accompanying text.

65. See note 41 supra. Demanding governors express little interest in gaining custody in such cases. See Letters from Cal., Ill., Iowa, Mich. (requisition withdrawn), N.C. But cf. Letter from Utah. This may be because the initiative for the proceeding is furnished by private individuals who seek ultimately to acquire civil jurisdiction. See ScoTr, INTERSTATE RENDITION $\$ \$ 145-56$ (1917); Letter from Montana.

66. Cf. Harrison v. State, 77 So. 2d 384 (Ala. App.), cert. denied, 262 Ala. 701, 77 So. 2d 387 (1955); Lincoln v. State, 199 Md. 194, 85 A.2d 765 (1952). 
cases are similarly accepted without protest by the demanding state. The denial is traditional and usually implies no criticism of the state requesting the fugitive ${ }^{67}$ the strength of the plea may even convince the demanding governor to withdraw his requisition. ${ }^{68}$ Although these equitable pleas seldom create friction, they are frequently combined with other merit defenses of more serious import which may lay the ground for interstate discord. ${ }^{69}$ Denial of rendition based on substantive defenses raises the issue of the guilt of the accused and can provoke an accusation that the asylum state has invaded the criminal jurisdiction of the demanding state. ${ }^{70}$ But in practice, because of their infrequency, substantive defenses create little harm to interstate relations.

Interstate disharmony may result from denials in which the asylum governor's reasoning is inadequate. Where no reasons or spurious technical grounds are given for denial, the demanding state's complaints generally originate with lesser officials rather than with the governor. These officials may criticize both the incompleteness of the refusals and the invalidity or triviality of any alleged technical defects, ${ }^{71}$ and they may retaliate by refusing rendition and giving similar inadequate reasons when the positions of the two states are reversed.7:

The most severe interstate conflict has resulted from rendition refusals based on due process violations in the demanding state. In such cases not only has the asylum governor set himself up as a judge of the propriety of the demanding state's actions, but his denial constitutes a belief in the truthfulness of the fugitive's allegations. ${ }^{73}$ Two cases in which denial of rendition was based on a plea of cruel punishment in the demanding state led to serious discord between the states, and to personal animosity between the governors involved.74

67. However, criticism may be implied from references to excessive punishment inflicted for the crime committed. See cases cited note 49 supra.

68. N.Y. Times, Nov. 28, 1951, p. 1, cols. 6-7, p. 52, cols. 3-4 (Governor Persons of Alabama recalled requisition, declaring fugitive had served enough time); N.Y. Times, March 15, 1952, p. 30, col. 3 (Governor Dewey of New York decided not to request fugitive because of apparent rehabilitation) ; cf. N.Y. Times, April 23, 1928, p. 16, col. 2.

69. N.Y. Times, Dec. 16, 1932, p. 3, col. 6; Aug. 6, 1948, p. 36, cols. 1-2. See note 51 supra and accompanying text.

70. For a factual situation in which the charge might have been made see N.Y. Times, Nov. 26, 1955, p. 9, cols. 2-3.

71. See Letters from Mich. and N.C.; cf. Letter from N.M. (governor himself indicates critical attitude).

72. Cf. Letter from New Mexico.

73. See, e.g., 22 SuRveY Graphrc 94, 95, 126 (1933).

74. The first case involved Robert E. Burns, a fugitive from a Georgia chain gang who had fled to New Jersey. N.Y. Times, Dec. 22, 1932, p. 1, col. 4, p. 3, cols. 4-6. For events leading up to the denial of rendition by New Jersey's Grovernor Moore, see N.Y. Times, Dec. 16, 1932, p. 3, col. 6; Dec. 18, 1932, p. 3, col. 1; Dec. 20, 1932, p. 40, col. 2; Dec. 21, 1932, p. 23, col. 1. Following the hearing the governor was accused of violating his constitutional oath, assailed by the demanding state's congressmen, and condemned for listening to evidence irrelevant to an extradition proceeding and against which the demanding state could not properly defend. N.Y. Times, Dec. 23, 1932, p. 7, cols. 1-2; Dec. 28, 1932, p. 36, col. 4; The Literary Digest, Jan. 7, 1933, pp. 9-10. The demanding governor, Richard B. Russell, of Georgia, called the refusal a "deliberate and wanton insult." Ivid. 
The present rendition policy of many governors indicates that similar disruptions of interstate relations are constantly possible. Governors continue to refuse extradition even in those situations where interstate cooperation has previously been injured. ${ }^{75}$ Unless rendition refusals are based on constitutionally admissible grounds, the asylum governor is always subject to criticism for not following the mandate of the Constitution and statutes. ${ }^{76}$ Furthermore, the asylum's action presents an excuse for retaliatory refusals by the demanding governor and a precedent for subsequent refusals by other governors. ${ }^{7 \pi}$ Not only do these disputes adversely affect the efficient administration of criminal justice, but they create tensions in other areas of interstate relations far removed from rendition. ${ }^{78}$

The asylum governor countered by pointing to prior refusals by other governors, including one by the demanding executive. N.Y. Times, Dec. 23, 1932, p. 7, cols. 1-2; Dec. 22, 1932, p. 1, col. 4, p. 3, cols. 4-6. The hearing itself had been held before a large audience in the state legislative chamber, with demonstrations occurring during the proceedings. N.Y. Times, Dec. 21, 1932, p. 23, col. 1; Dec. 22, 1932, p. 1, col. 4, p. 3, cols. 4-6; 22 SURvey Graphic 94, 95-97, 126 (1933). See, generally, Comment, 67 U.S.L. Rev. 58 (1933).

In the second case, refusal to extradite by Governor Hurley of Massachusetts led to a long standing personal feud with Governor Rivers of Georgia ; the latter retaliated by paroling a prisoner on condition that he go to the asylum state. N.Y. Times, Sept. 2, 1937, p. 8, cols. 4-5; Sept. 3, 1937, p. 6, col. 6 . The dispute began when Hurley refused extradition of a Negro who had escaped thirteen years previously from a chain gang. Hurley pointed to the abuse of prisoners in Georgia. N.Y. Times, July 28, 1937, p. 9, col. 2. The feud was referred to at the next governor's conference. Address by Governor Allred of Texas, Governors' Conference 169 (1937). The feud was renewed when Hurley refused to extradite a fugitive wanted in Georgia on a nonsupport charge. N.Y. Times, May 28, 1938, p. 3, col. S. For criticism of Hurley and Governor Moore of New Jersey, see N.Y. Times, Sept. 5, 1937, \$ 4, p. 8, col. 3.

Other examples of interstate controversies resulting from due process cases are discussed in N.Y. Times. Dec. 5, 1952, p. 11, col. 5 ; Editorial, 12 BENCH \& BAR (n.s.) 280 (1917).

Judges denying rendition on due process grounds have been subject to similar criticism. See Hale v. Crawford, 65 F.2d 739 (1st Cir.), cert. denied, 290 U.S. 674 (1933), discussed in Comment, 43 Yale L.J. 444 (1934), and 136 The Nation 517 (1933); Johnson v. Dye, 175 F.2d 250 (3d Cir.), rev'd per curian, 338 U.S. 864 (1949), discussed in N.Y. Times, Sept. 25, 1949, p. 82, col. 3; DeGraffenreid, Law of Extradition, 2 ALA. L. Rev. 207 (1949); Note, 2 Stan. L. Rev. 174 (1949).

75. See note $5 S$ supra and accompanying text. Only two jurisdictions indicate no denials will issue in merit cases. Letters from Alaska and Ore.

76. See note 5 supra and accompanying text. See also, Dean, Inter-State Rendition in Its Constitutional Aspects, 55 Albany L.J. 102 (1897).

One writer states that only the infrequency of the cases removes the ground for concern. Comment, 67 U.S.L. Rev. 58, 64 (1933). But cf. Hoague, Extradition Between States, 13 AM. L. REv. 181, 184 (1879).

77. See, $c . g$., the Hurley-Rivers feud, note 74 supra. See also Mosk, Extradition Procedure in California, 14 CaLIF. ST. B.J. 121, 125 (1939) (fear of such refusals). For the use of prior refusals as precedents see N.Y. Times, March 25, 1925, p. 4, col. 2; Dec. 23, 1932, p. 7, cols. 1-2 (case of Robert E. Burns; see note 74 supra).

78. Refusals might well result in antagonism at regional conferences of governors and other officials where "oil and gas conservation, tax collections, truck licensing, and many other important things" depend on reciprocity between states. Letter from New Mexico. 


\section{Attempted Control of the Governor}

The possible adverse effects on interstate relations resulting from the governor's use of discretion have inspired many proposals to restrict his power. Under one view, the Supreme Court should repudiate Kentucky v. Dennison 70 and permit federal mandamus of the governor. Thus, rendition would automatically result when fugitivity and substantial charge are shown. ${ }^{80}$ Proponents of this solution argue that Dennison was decided wrongly since the constitutional drafters would never have included a provision mandatory in language but unenforceable in practice. ${ }^{81}$ However, there is little likelihood that the time-honored Dennison rationale will be overruled in the extradition context. ${ }^{82}$ Furthermore, Dennison has certain advantages aside from reducing areas of federal-state disharmony. ${ }^{83}$ Mandamus proceedings of this nature would be brought directly to the Supreme Court, ${ }^{84}$ which could not take into account the pressures that underlie the most difficult rendition cases. It would seem preferable to utilize the relatively informal executive hearings to enable the governor to deal more directly with the competing interests concerned.

A second proposal within the context of formal extradition procedures would vest the rendition power in lesser executive or judicial officers who would be

Political entanglements may also result. When New York's Governor Smith was a candidate for the presidential nomination, he felt compelled to deny that he had refused to extradite Negroes to the South because they would not receive fair trials. N.Y. Times, Nov. 29,1927 , p. 3, col. 4. New York's Governor Harriman faced a similar problem. N.Y. Times, Nov. 26, 1955, p. 9, cols. 2-3.

79. 65 U.S. (24 How.) 66 (1861).

80. See notes $39-40,47,56$ and 58 supra.

81. Coleman, The State as Defendant Under the Federal Constitution: the VirginiaWest Virginia Debt Controversy, 31 HARv. L. Rev. 210, 230-32 (1917) ; Dean, supra note 76 , at 103-07 (1897).

The Court's opinion has been attributed to Chief Justice Taney's states' rights theories. Smith, Roger B. Taney: Jacksonian Jurrst 32, 102, 151 (1936); Dean, supra note 76, at 104-05; Note, 2 Miss. L.J. 240, 243 (1929). But see Palder, Marshall and TaNey 258-61 (1939).

82. The Denmison rationale seems to have met with general approval soon after it was decided. Hoague, supra note 76 , at 225 . The case was criticized at a later date. Coleman, supra note 81, at 245; Holcombe, The States As Agents of the Nation, 1 S.W. Pox. Scr. Q. 307, 315 (1921); cf. Warren, The Supreme Court and Soveretgn States S0-\$1, 157 (1924). But there has been no discussion of the case in recent years.

83. Chief Justice Taney impliedly based his opinion on fear of such conflict. Kentucly v. Dennison, 65 U.S. (24 How.) 66, 107-08 (1861). See Swisher, Roger B. TANey 545 (1935); Sterner, Lrfe of Roger B. TANey 442 (1922); PALMer, op. cit. supra note $\$ 1$, at 260-61; Holcombe, supra note 82, at 314-15. See also note 3 sutra. For evidence that this fear is not unwarranted see the response to the school segregation cases, Brown v. Board of Education, 347 U.S. 483 (1954), discussed in Comment, 65 YALE L.J. 630 (1956).

84. See U.S. Const. art. III, $\S 2$, cls. 1,2 ; note 9 supra. See also Virginia v. West Virginia, 246 U.S. 565, 598-99 (1918) ; Georgia v. Pennsylvania R.R., 324 U.S. 439, 450 (1945). 
subject to mandamus in all courts. ${ }^{85}$ However, the central role which the governor plays in the rendition process is not only firmly established in tradition, but constantly accentuated in recent uniform legislation. ${ }^{86}$

Other proposals have attempted to avoid the governor's discretion by circumventing the formal extradition procedure. The Fugitive Felon Act gives the federal courts in the demanding state jurisdiction over persons fleeing across state lines to avoid state prosecution or confinement for certain felonies. ${ }^{87}$ Once the fugitive is returned by the easier federal procedure, the fact that his return was for a limited purpose does not preclude the demanding state from prosecuting him for the state offense. ${ }^{88}$ Despite the possibility of extensive use,

85. Cockrill, Statement of Law Concerning Domestic Fugitives from Justice (1874) (in support of a bill, 3 CoNG. REc. 20 (1874), placing extradition power in magistrates); Spear, The Newi Extradition Bill, 37 AlbaNy L.J. 88 (1888) (Congress could constitutionally confer rendition power on magistrates or other state officers); 2 Moone, Extrauition $\$ 534$ (1S91) (authority should be placed in federal officers); Moore, The Difficultics of Extradition, 1 ACAD. Pox. Scr. Proc. 625, 634 (1911); Editorial, 26 BENCH \& BAR 3, 9 (1911) ; Governors' Conference on CRIME 365-67 (New York 1935) (proposal by Commercial Crime Commission for interstate compact to put power in local court or magistrate without need for requisition papers); Note, 54 HARv. L. REv. 508 (1941) (if discretion is to be eliminated, take power out of governor's hands; alternatively vest power in judicial officers who are subject to review).

Federal courts can mandamus lesser state officials. Huidekoper v. Hadley, 177 Fed. 1 (Sth Cir. 1910), appeal dismissed, 223 U.S. 735 (1911) ; Board of Liquidation v. McComb, 92 U.S. 531 (1875). Such actions are not suits against the state for purposes of the Eleventh Amendment. General Oil Co. v. Crain, 209 U.S. 211 (1908). State courts can also mandamus lesser state officials. E.g., People ex rel. O'Meara v. Smith, 374 Ill. 286, 29 N.E.2d 274 (1940). See also Sherwood, Mandamus to Reviezo State Administrative Action, 45 Mich. L. Rev. 123, 139-62 (1946).

86. See note 12 supra and accompanying text.

Several statutes have attempted to restrict the governor's position. The UNIForm Criminal Extradition Act $\S 13$ and 14, and the Uniforar Fresh Pursutr Act $\$ 2$, providing for arrest prior to requisition, may restrict the asylum governor's factual determination of fugitivity, note 40 supra. Where the fugitive is arrested under the former act, a magistrate can detain the prisoner only after he determines, inter alia, the fugitivity of the accused. Under the latter act, the magistrate must determine whether the arrest was "lawful," and to be lawful the fugitive must have been taken in fresh pursuit. Any refusal by the asylum governor based on fugitivity would be a repudiation of a finding of the magistrate. See also note 11 stipra (Criminal Extradition Act); HandBook on INTERstate Crime Control 1, 3 (rev. ed. 1949) (Fresh Pursuit Act adopted in thirty-six jurisdictions).

S7. 18 U.S.C. $\$ 1073$ (1952). The act also makes it a crime to flee to avoid giving testimony in a state criminal proceeding which charges commission of a penitentiary offense. For comment on the act see, generally, Toy \& Shepherd, The Problem of Fugitive Felons and Withesses, 1 Law \& Conteasp. Prob. 415 (1934); Note, 48 Colum. L. Rev. 1.190, 1198 (1948).

S\&. United States v. Conley, S0 F. Supp. 700 (D. Mass. 1948); Note, 22 So. Calif. L. REv. 474 (1949). The act is specifically designed to aid the states in enforcement of their criminal laws. United States v. Brandenburg, 144 F.2d 656, 659 (3d Cir. 1944). The act was held constitutional in Hemans v. United States, 163 F.2d 228, 238-40 (6th Cir.), cert. dinicd, 332 U.S. 801 (1947). 
the Felon Act has been restricted by limitation of the act to particular felonies, ${ }^{89}$ the need to show actual flight and intent to avoid state prosecuion, ${ }^{90}$ and perhaps by the reluctance of federal authorities to apprehend fugitives wanted for certain state crimes.91 - More widely used is the Uniform Act for Out-of-State Parolee Supervision, ${ }^{92}$ providing for rendition of probationers and parolees without the need for any extradition proceedings or other formalities. Under the act, if a probationer or parolee enters a receiving state under an agreement between that state and the sending state, the latter may retake him without any preliminary hearing. Although the prisoner may challenge the retaking by a writ of habeas corpus, the demanding state can justify its arrest merely by showing the authority of its officer and the identity of the person retaken. ${ }^{03}$ The Uniform Act to Secure Attendance of Witnesses gives an asylum state judge power to deliver a fugitive witness after he determines that the witness is "material and necessary" for a criminal prosecution or grand jury proceeding in the demanding state. ${ }^{04}$ This procedure eliminates the former practice of charging the witness with a crime to lay the foundation for a rendition proceeding. ${ }^{95}$ The Uniform Reciprocal Enforcement of Support Act also makes rendition unnecessary in many cases. Its civil provisions permit an aggrieved

89. See United States v. Brandenburg, supra note 88 ("burglary with explosives" does not charge "burglary" under the act).

90. See Barrow v. Owen, 89 F.2d 476, 478 (5th Cir. 1937) ; Note, 54 HARv. L. REv. 508,509 (1941).

91. See N.Y. Times, Nov. 4, 1955, p. 4, col. 7 (governor of South Carolina condemned United States Dep't of Justice for refusing to enter case of anti-segregationist Negro minister charged with assault).

92. The Parolee Act is now in effect in forty-five states. HandBook on Interstate CrRAre Control 49 (rev. ed. 1949). It is an interstate compact passed under authority of the Federal Crime Prevention Compact Act. 4 U.S.C. $\$ 111$ (1952). The Parolee Act was the product of the Interstate Commission on Crime. See note 11 supra. See also Shemel, Reaching the Extrastate Fugitive, 16 B.U.L. REv. 595, 596 (1936).

93. Uiniform Act for Out-of-State Parolee Supervision $\$ 1(3)$; Pcople ex rel. Barrett v. Bartley, 383 Ill. 437, 50 N.E.2d 517 (1943); Letter from Oregon; HANDEook on Interstate Crime Control 46-84 (rev. ed. 1949); Note, 48 Colun. L. Rev. 1190, 1198 (1948). The act has been held constitutional. Gulley v. Apple, 213 Ark. 350, 210 S.W.2d 514 (1948) ; Ex parte Tenner, 20 Cal. 2d 670, 128 P.2d 338 (1942). See also note 10 supra.

Prior to the act, the fugitivity of the parolee might have been contested by a showing that he left the demanding state with its permission. Although the defense was typically unsuccessful, Taylor v. Foster, 205 Ga. 36, 52 S.E.2d 314 (1949); People $e x$ rel. Ross v. Becker, 382 IIl. 404, 47 N.E.2d 475 (1943), it was frequently raised. A second contention formerly made was the illegality of the parole revocation-a substantive defense. This plea also met with little success. See cases cited note 52 supra; cf. Letter from Oregon. But of. Mosk, supra note 77, at 124.

94. Unifora Act to Secure Attendance of Witnesses \$2. See, generally, Note, 31 Mrnw. L. Rev. 699, 707-10 (1947). The act has been adopted in forty-three jurisdictions. 9 UNIFoRKr Laws ANn. 33 (Supp. 1955).

Rendition of witnesses may similarly be accomplished under the Federal Fugitive Felon Act. See note 87 and text at notes $87-88$ supra.

95. See note 41 supra. 
party to enforce a civil decree of the demanding state in the asylum state. ${ }^{96}$ These attempts to restrict and avoid the governor's discretionary power have probably succeeded in decreasing the number of rendition refusals. ${ }^{97}$ However, they do not affect the situations that are most explosive, and recurring cases in which fugitives contest rendition indicate that numerous opportunities remain for disruption of interstate relations.

\section{A Pragisatic Solution}

\section{Recognition of Limited Discretion}

Total abolition of executive discretion is both unrealistic and unwise. A more desirable solution would recognize the propriety of gubernatorial discretion but would confine it to cases where its exercise is consistent with interstate harmony. Interstate relations and the administration of criminal justice are not always impaired by a denial of rendition on nonconstitutional grounds. For example, in cases where extradition was refused because of an equitable

96. The act was originally promulgated by the Commissioners on Uniform State Laws in 1950, 1950 HANorook of Commissioners 171, but later amended, 1952 HaNdrook of Commissioners 291. It has been adopted in the original or amended form in forty-eight jurisdictions. 9A Uniforar Laws AnN. 68 (Supp. 1955). For executive reaction to failure to use the civil provisions of the act, see note 45 supra and accompanying text.

97. There have been several other proposals to change the governor's role in rendition to solve the prablem. One suggestion is to set up federal machinery to arrest and deliver the fugitive. Larremore, Inadequacy of the Present Federal Statute Regulating Interstate Reudition, 10 Colum. L. Rev. 208, 217, 219-20 (1910). See Cook, The Powers of Congress Under the Full Faith and Credit Clanse, 28 YALE L.J. 421, 427 n.19 (1919). But cf. Spear, supra note 85 , at $92-93$ (rendition should be performed by the states as the regulation of fugitives comes within the purview of state rights and powers).

A second suggestion is to increase the scope of judicial review on habeas corpus. See Horowitz \& Steinberg, The Fourteenth Amendment-Its Necoly Recognized Impact on "Scope" of Habeas Corpus in Extradition, 23 So. Calif. L. Rev. 441 (1950); Note, 28 TEMr. L.Q. 272 (1954). But see Note, 1. J. Pub. L. 463 (1952). Such broadened inquiry might induce governors to extradite more often, leaving the major determination to the courts. See Hoague, supra note 76 , at 243 . There is doubt whether asylum courts can constitutionally inquire into matters which have nothing to do with fugitivity or substantial charge.

It has also been proposed that a requisition issue only after a probable cause showing in the demanding state. Note, 54 HaRv. L. REv. 508, 509 (1941). It is contemplated that fewer requisitions will issue and consequently that fewer cases will reach asylum governors. However, current procedure requires some probable cause showing to obtain the indictment, information or affidavit which is a prerequisite to rendition authority, note 18 supra. A further showing would seem to be of little use. In Ohio, by statute, the governor should not issue a request unless the application was made in good faith. OHro REv. Cone ANN. tit. 29, \$2963.29 (Page 1954).

However, one writer has given recognition to discretion by proposing that a probable cause rule, similar to that in effect in international extradition, note 56 supra, be established for habeas corpus proceedings in the asylum state. Scotr, InTERstate Rendition $\$ 158$ (1917). Adoption of this suggestion would permit alleged fugitives to introduce evidence of innocence. 
plea, demanding states have generally been unconcerned. ${ }^{98}$ On the other hand, interstate harmony is most strained when denial implies an accusation of unconstitutionally low standards of criminal administration in the demanding state. $^{98}$

The phrase "moral duty," which the Supreme Court used to describe the asylum governor's obligation, ${ }^{100}$ may aid in developing criteria for the scope of discretion which will be fair to both the asylum and demanding states. For the asylum governor has an obligation to his state and its citizens as well as to the demanding state, ${ }^{101}$ and these obligations, which would conflict if considered absolute, may perhaps be reconciled if viewed as moral duties. Thus, the asylum governor should exercise his discretion if the asylum state has a substantial interest in retaining a fugitive and if this interest outweighs that of the demanding state in recovering him. ${ }^{102}$ The essential facts to establish the asylum state's interest and to avoid prosecution or return to imprisonment include the length of time the fugitive has lived in the asylum state, his contributions to the community in which he has resided, his standing in that community, and the presence of a family and others dependent on him. ${ }^{103}$ Only after the asylum governor has assessed the interest of his state should he attempt to weigh the demanding state's interest. The latter's interest should always be considered substantial but its precise valuation should be influenced by the length of time to be served in the demanding state and by the seriousness of the offense charged. ${ }^{104}$ This, of course, is the type of appraisal which would be made by a prosecutor in the demanding state, but many of the factors which determine whether prosecution or return to imprisonment are warranted seem to be particularly within the cognizance of the asylum state and can be better determined there. When a fugitive is in the asylum only temporarily, that state should make no attempt to determine the desirability of extradition, for its interests are not involved, and its ability to gauge the merits of prosecution is no greater than that of the demanding state. A substantial interest analysis would preclude consideration of substantive defenses and due process claims as they do not affect the substantial interests of the asylum state. These questions should be left for the courts of the demanding state where more effective adjudication is assured. Moreover, if in the demanding state the fugitive establishes his right to freedom, the interest of the asylum will have been harmed only slightly in comparison to the greater harm that the demanding state might have suffered if rendition were denied. The substantial interest test could be

98. See notes 67-68 supra and accompanying text.

99. See notes 73-74 supra and accompanying text.

100. Kentucky v. Dennison, 65 U.S. (24 How.) 66, 107-10 (1861.). See note 16 supra and accompanying text.

101. See Letter from New Jersey.

102. Cf. Comment, 67 U.S.L. Rev. 58, 63 (1933) (though not supported by the letter of the law the governor's refusal may serve the interests of substantial justice).

103. See notes 48-49 supra and accompanying text.

104. See note 49 supra and accompanying text. 
given effect by a joint declaration of state executives, possibly at the annual Governors' Conference, which has previously served as a forum for rendition problems. ${ }^{105}$

Examples of other common law countries having either a federal system of government or a variant of it provide support for the employment of discretion in replying to extradition requests. Section 10 of the Fugitive Offenders Act of Great Britain gives a superior court the discretionary power to discharge a person demanded by another part of the Commonwealth if his return, "by reason of the trivial nature of the case or . . the application ... not being made in good faith in the interests of justice or otherwise," would, "having regard to the distance, to the facilities of communication, and to all the circumstances of the case, be unjust or oppressive."106 This provision was probably enacted because of the extension of inter-Empire rendition to misdemeanors, ${ }^{107}$ but British courts have discharged a fugitive when the offense charged was a serious one, and they have not been limited in their considerations by any good faith doctrine. ${ }^{108}$ Similar rendition legislation vesting discretionary power in judicial officers has also been enacted in Australia, ${ }^{109}$ and executive authorities in India possess discretionary power by statute. ${ }^{110}$

105. E.g., Governors' Conference 169-89 (1937) ; 2 Governors' Conference 134-56 (1910). Elpern, Important Phases of the Law of Interstate Extradition, in Ass'N or GRAND Jurors of New York County, Interstate Exchange of Witnesses and Interstate ExtRAdition 12, 20 (1929) (true remedy for discretion is agreement between governors, not federal legislation).

106. $44 \& 45$ VICT., c. $69, \S 10$ (1881). A superior court in England is the Court of Appeal and the High Court of Justice. Id. $\$ 39$. Similar discretionary power was given to colonial magistrates. Id. \& 19. See, generally, Piggotr, Extradition 281-\$2, 285 (1910).

It is to be noted that the British have no concept of non-fugitivity as a defense. A person is subject to extradition once he is properly accused of having committed an offense. 44 \& 45 VICT., c. 69, \$2 (1881).

107. See id. §9. The prior fugitive act applied only to treason and some felonies. $6 \&$ 7 VICT., c. 34 (1843). It was later amended to apply to all felonies. 16 \& 17 VICT., c. 118 (1853). These earlier acts provided no discretionary power. Apparently there was a fear that extension of the act to all offenses would cause extradition, to distant points of the Empire, of persons accused of minor offenses, possibly crimes unknown to the asylum. See Note, 5 L.J. 517 (1870).

108. The courts seem to consider the unjust and oppressive allegation in light of all the circumstances without applying the literal construction of $\S 10$. Rex v. Brixton Prison Governor, [1951] 1 T.L.R. 1155 (K.B.). Cf. The King v. Governor of Brixton Prison, [1910] 2 K.B. 1056 (C.A.); $R e$ Government of India and Mubarak Ali Ahmed, [1952] 1 All E.R. 1060 (Q.B.). Courts generally have been restrained in applying the discretion granted by $\$ 10$. See Re Henderson, [1950] 1 All E.R. 283 (C.A.) (unusual delays of proceedings will not justify discharge where alleged offense is serious and where delays are not caused by prosecution). See Note, 3 INT'L L.Q. 409, 410 (1950).

109. Service and Execution of Process Act, 1901-1953, § 18(6), 1 Commonw. Acts 175 (1901-02), as amended, [1953] Commonw. Acts 178. A magistrate or justice of the peace is invested with the discretionary power. The act was passed to end the difficulties of extraditing between the states. See Cook, supra note 97, at 426-27. Cf. Note, 5 L.J. 320 (1870).

Section 19 of the act provides that a judge of the supreme court of the state or part of the Commonwealth in which the accused is apprehended shall, on application of either party, 


\section{Procedural Changes}

With the recognition of discretion in interstate rendition, procedural changes should be enacted in the executive hearing system to assure that only the legitimate interests of the asylum state will be used to justify denial of rendition. These changes could be added by amendment of the Uniform Criminal Extradition Act. ${ }^{111}$ The asylum governor's hearing should be held approximately two weeks after the fugitive's timely request. The brevity of the interval may deny to various pressure groups the time necessary to exert their influence, ${ }^{112}$ but the period should give all parties an opportunity to prepare their cases. ${ }^{113}$ At the time he schedules the hearing, the asylum executive should give notice to the demanding state so that it can appear to present its side of the case. ${ }^{114}$ In the interim prior to the hearing the fugitive should be required

review the decision. The judge may confirm, vary or quash the order and substitute a new order in its place.

The few cases construing the act indicate discretion will be exercised only when a minor offense is charged. Ffrost v. Stevenson, 58 Commw. L.R. 528, 607-08 (Austr. 1937) (discretionary provisions of Fugitive Offenders Act and Service and Execution of Process Act construed concurrently); O'Donnell v. Heslop, [1910] Vict. L.R. 162 (Austr.). Cf. In re Hatherly, [1940] Queensl. S.R. 20 (Austr.). But see Lourey v. Lourey, 35 Queensi. J.P. 31 (Austr. 1941); King v. Boyce, [1904] Queensl. S.R. 181 (Austr.).

Canada has no need for extradition since a fugitive may be arrested in any of the provinces. Dawson, The Government of Canada 34, 75, 100, 439 (1949).

110. Chapter III of the Indian Extradition Act, 1903 (Act No. XV of 1903) provided, inter alia, for rendition of fugitives between British India and the native states. See, generally, Sen, The Indian States 122-25 (1930). Section 7(1) provided that the political agent of a native state might issue a warrant to a district magistrate in British India. Section 15 gave the government of India or the local government power to stay the proceedings, cancel the warrant and discharge the alleged fugitive. By the Adaptation of Laws Order of 1950 the present government of India amended $\$ 7(1)$ and preserved the Act of 1903 where applicable, impliedly keeping $\$ 15$ in force.

Section 15 pre-empts the jurisdiction of an appellate court to inquire into the propriety of a warrant, Emperor v. Huseinally, 7 Bomb. L.R. 463 (India 1905), unless the warrant is plainly illegal, Goulter v. Emperor, [1935] All India R. 244 (Sind). However, an appellate court can review the district magistrate's refusal to submit a report to the central government for a stay of the proceedings or cancellation of the warrant under $\$ 15$. Lodhi v. Shyam Lal, [1950] All India R. 100 (Al1.). But see Sandal Singh v. District Magistrate, [1934] All India R. 148 (All.).

For discussion of rendition in federal states generally, see Ibrahin, Applicatron of Int'l Law in Disputes Between Member-States of Federal Unions 78-80 (1952).

111. See notes 11 and 44 supra. Amendments to the act would provide the uniformity necessary in rendition proceedings. Although rendition procedure is substantially uniform, there has been criticism of its variations. See Letter from New Mexico; Elpern, supra note 105, at 26 (standards of proof used by governors). Gubernatorial adherence to these amendments would be no more enforceable than other ministerial duties. See notes 9 and 13-15 supra and accompanying text.

112. See notes 59-63 supra and accompanying text.

113. See Letter from New Mexico suggesting seventy-two hour period; Glander, Practice in Ohio Under the Uniform Criminal Extradition Act, 8 Oнг Sт. L.J. 255, 260 (1942) (within two days after receipt of extradition papers).

114. See notes 29 and 63 supra and accompanying text. 
to file a list of the defenses he will present; a copy of these defenses should be sent to the demanding state and at the hearing the fugitive should be limited to them. This provision will prevent the accused from making surprise claims.115

An extradition bureau should be permanently established by legislation even in states where the governor presides over the hearing, to provide the consistency and expertise needed to determine rendition cases. ${ }^{116}$ However, the governor should be the responsible official because he alone possesses the discretionary privilege and because he is more responsive to possible adverse effects on interstate relations. Although the governor should be guided by a transcript of the testimony and a detailed report and recommendation from the extradition bureau, ${ }^{117}$ the demanding state should assume that the determination is the governor's and not a lesser official's. The decision should be made shortly after the conclusion of the hearing, perhaps within three days, to minimize the effect of extra-hearing influences. When rendition is denied the governor should communicate detailed findings of fact and reasons for refusal to the demanding state which can then properly criticize the asylum state's action..$^{118}$

\section{CONCLUSION}

The constitutional theory of interstate rendition gives no discretion to an asylum state governor once statutory requirements are fulfilled by the demanding state. However, pragmatically viewed, discretion to deny rendition exists, and governors exercise it regularly. Interstate disharmony which has resulted from such refusals in the past constantly looms as a possible bar to interstate cooperation. Recognition by demanding and asylum officials alike of a proper basis for executive discretion may reduce the occasions when its exercise will produce adverse effects. Examples from both foreign and domestic practice

115. See note 74 supra.

116. Cf. Letter from New Mexico. The foremost example of inconsistent decisionmaking has been New Jersey. Compare N.Y. Times, Dec. 22, 1932, p. 1, col. 4, p. 3, cols. 4-6 (Governor Moore refused rendition after extended hearing on Georgia chain gang fugitive; see also note 74 supra) and N.Y. Times, Aug. 6, 1948, p. 36, cols. 1-2 (Governor Driscoll recalled warrant of ex-Governor Edge and refused extradition after "weighing ... the demands of justice"), with N.Y. Times, Jan. 18, 1938, p. 2, col. 4 (Governor Hoffman extradited a few hours before leaving office; attorney-general said that the "question of innocence cannot be tried here nor are we justified in examining into the question whether the prisoners in the state of South Carolina are mistreated") ; N.Y. Times, June 12, 1943, p. 15, col. 6 ; July 10, 1943, p. 11, col. 5 (Governor Edison granted rendition of Georgia chain gang fugitive) ; and N.Y. Times, Aug. 16, 1944, p. 21, col. 7 (Governor Edge extradited, suggesting clemency for fugitive).

The usual absence of executive orders specifying the proper procedure to be followed, e.g., Letters from Cal., Ga., Ohio, probably contributes to the inconsistency.

117. These aids to decision are part of the practice in many jurisdictions. See notes 31-33 supra and accompanying text. They will become more necessary if the brief periods suggested here are adopted.

118. See notes 36 and 63 supra and accompanying text. 
reveal a widespread acceptance of discretion in certain areas. Conformity to a national standard, even if it imposes less than a ministerial duty, will satisfy demanding states of the fairness of decisions refusing their requests. Recognized criteria offering asylum governors the opportunity to retain fugitives in whom they have legitimate interests may make them willing to forsake the unrestrained but highly disputed power they now possess.

Executive discretion will operate more satisfactorily if certain procedural reforms are adopted for the executive hearing. Most important are techniques to assure demanding states of adequate representation and to limit extra-hearing pressures. Also significant is the establishment of rendition bureaus to introduce consistency in decision-making within a jurisdiction. Similar action in every state will produce uniform treatment from jurisdiction to jurisdiction. The resultant predictability of rendition determinations would allow governors to accept without discord those refusals which occur in recognized situations. 